\title{
ANALISIS HUBUNGAN TINDAK AGRONOMI DAN SIFAT KIMIA TANAH TERHADAP PRODUKTIVITAS DAN RENDEMEN MINYAK ATSIRI BUNGA MELATI DI KABUPATEN BANJAR
}

\author{
(Relationship Analysis Of Agronomic Actions And Soil Chemical Properties On Productivity And \\ Essential Oil Of Jasmine Flowers In Banjar District)
}

Indriani, Hilda Susanti, dan Bambang Fredrickus

Program Studi Magister Agronomi Fakultas Pertanian Universitas Lambung Mangkurat Jalan A. Yani Km. 36 Kotak Pos 1028 Banjarbaru 70714 Telpon/Fax. (0511) 4772254

Penulis Koresponden: iinindriani8@gmail.com

Article Submitted: 27-08-2021

Article Accepted: 07-01-2022

\begin{abstract}
Banjar Regency in South Kalimantan is the center of jasmine production. The productivity level of the province of South Kalimantan cannot make a large contribution to national jasmine production because the harvested area of South Kalimantan is less competitive than Central Java, this is unforgettable because there are differences in agronomic actions and soil chemical properties. This study analyzed the relationship of agronomic actions and soil chemical properties and the dominant traits affecting the productivity of jasmine in the Banjar Regency. This study adopted survey methods and field observations. The survey method included determining the sampling locations and interviews with jasmine farmers. The selected villages were determined by purposive sampling method by deliberately choosing villages that were dominant in cultivating jasmine plants, namely Labuan Tabu village, Jingah Habang Ilir village, and Pandak Daun village. The results revealed that the agronomy action and soil chemical properties simultaneously had A significant effect on the yield of jasmine. Each of the treatments of nitrogen application, potassium application, and pruning frequency significantly affected the yield of jasmine. The dominant agronomic actions on the yield of jasmine were nitrogen application, pruning frequency, and potassium application, with the contribution of $46.51 \%$, $17.72 \%$, and $17.14 \%$, respectively. The indirect effect of nitrogen fertilizer application channeled through the pruning frequency contributed $18.19 \%$ higher than the direct effect of the pruning frequency alone. The indirect effect of potassium fertilizer application through the pruning frequency contributed $16.33 \%$ to the jasmine productivity. The application of $\mathrm{N}$ fertilizer and the pruning frequency showed a very significant and positive linear relationship to productivity with regression equations of $5.173+0.01526 \mathrm{~N}$ and $-0.194+3.587$ Fpks, respectively.
\end{abstract}

Keywords: Agronomic Actions, Banjar, Jasmine, Soil

\section{PENDAHULUAN}

Bunga melati erat kaitannya dengan kehidupan sosial masyarakat Indonesia sehingga konsumen bunga melati mencakup segala kalangan masyarakat. Keadaan ini dapat menguntungkan petani pembudidaya bunga melati, dengan catatan jika budidaya, produksi dan pemasaran yang baik dan lancar (Bastiah, 2019).

Salah satu etnis yang masih memegang teguh budaya dan memanfaatkan tumbuhan bunga-bungaan adalah masyarakat suku Banjar di Kabupaten 
Banjar Kalimantan Selatan. Contoh pemanfaatan bunga - bungaan pada berbagai ritual yang khas di masyarakat Banjar seperti untuk ritual betapung tawar, mandi-mandi, upacara kematian, perkawinan, khitanan, dan acara keagamaan (Nababan, 2003). Berdasarkan informasi ketua adat, penggunaan tumbuhan berbunga oleh masyarakat suku banjar diwariskan secara turun menurun. Selain dijual dalam bentuk segar tanaman melati mempunyai peluang besar yang dikelola menjadi produk turunan seperti minyak atsiri yang berpotensi sebagai minyak aroma terapi dan sebagainya (Direktorat Jendral Hortikultura Kementrian Pertanian, 2020).

Potensi melati untuk usaha agribisnis cukup besar untuk pemenuhan kebutuhan dalam negeri maupun ekspor. Besaran nilai ekspor bunga melati dari Jawa Tengah sejak Agustus 2018 sampai Januari 2019 senilai 200,55 miliar rupiah. Komoditas ini diekspor ke beberapa negara seperti Arab Saudi, Malaysia, Singapura dan Thailand (Tabloid sinartani, 2019). Sentra melati di Indonesia terdapat di Provinsi Jawa Tengah (Kab. Pemalang, Kab. Batang, Kab. Purbalingga dan kab. Pekalongan), Provinsi Jawa Timur (Kab. Pasuruan dan Kab. Bangkalan) dan Provinsi Kalimantan Selatan (Kab. Banjar) (Direktorat Jendral Hortikultura Kementrian Pertanian, 2020).

Kabupaten Banjar di Kalimantan Selatan merupakan sentral produksi tanaman melati berdasarkan data tahun 2017-2019 produktivitasnya adalah $10,58 \mathrm{t} \mathrm{ha}^{-1}$ (DTPH Kabupaten Banjar, 2020). Tingkat produktivitas ini masih lebih rendah dibandingkan dengan produktivitas di daerah Jawa Tengah yaitu $37.81 \mathrm{t} \mathrm{ha}^{-1}$ (Statistik Tanaman Hias Indonesia, 2018). Daerah penyumbang hasil bunga melati terdapat di Kecamatan Martapura (Desa Labuan Tabu, Desa Bincau) dan Kecamatan Karang Intan (Desa Jingah Habang Ulu, Desa Pandak daun dan Desa Jingah Habang Ilir) (Direktorat Jendral Hortikultura Kementrian Pertanian, 2020).
Tingkat produktivitas provinsi Kalimantan Selatan tidak dapat memberikan sumbangan yang besar terhadap produksi melati nasional karena luas panen Kalimantan Selatan kalah bersaing dibanding Jawa Tengah dan tindak agronomi yang digunakan petani masih sederhana. Permasalahan lain yang terjadi di Kalimantan Selatan khususnya Kabupaten Banjar adalah terjadi perbedaan jumlah produksi melati antar desa produsen. Hal ini diduga karena terdapat perbedaan tindak agronomi para petani produsen dan sifat kimia tanah antar desa.

Tindak agronomi melati merupakan suatu tidakan manusia mengenai budidaya atau penerapan teknologi dalam kegiatan budidaya melati agar mendapatkan produksi yang baik, sedangkan sifat kimia tanah berhubungan dengan peristiwa-peristiwa kimia baik diatas permukaan tanah atau didalam tanah yang akan menentukan status kesuburan tanah. Oleh karena itu, perlu di analisis hubungan tindak agronomi dan sifat kimia tanah terhadap produktivitas dan rendemen minyak atsiri bunga melati di Kabupaten Banjar.

\section{METODE PENELITIAN}

\section{Tempat dan Waktu Penelitian}

Penelitian ini dilaksanakan pada 2 Kecamatan yaitu Kec. Martapura dan Kec.Karang Intan Kabupaten Banjar Provinsi Kalimantan Selatan, dimulai dari Bulan April hingga Bulan Juni 2021.

Prosedur dan Pengumpulan Data

Jenis dan sumber data

Data penelitian yang dikumpulkan adalah data utama dan data pendukung. Data utama adalah data tindak agronomi, sifat kimia tanah dan rendemen minyak atsiri dari bunga melati. Data utama diambil secara langsung dari hasil wawancara dengan petani melati. Data penelitian sekunder atau pendukung merupakan penunjang yang didapatkan dari instansiinstansi pemerintah, referensi serta publikasi pendukung lainnya. 


\section{Metode Pengumpulan Data}

Metode pengumpulan data meliputi metode survey, observasi dan laboratorium. Metode survey meliputi penentuan lokasi pengambilan sampel dan wawancara dengan petani melati. Desa yang dipilih ditentukan melalui metode purposive sampling yaitu dengan sengaja memilih desa yang dominan membudidayakan tanaman melati, yaitu desa Pandak Daun, Labuan Tabu, dan desa Jingah Habang Ilir. Setiap desa sampling diambil sebanyak 10 responden sebagai sampel, sehingga jumlah sampel yang diperlukan adalah sebanyak 30 responden. Pemilihan sampel pada masing-masing lokasi desa sampel dilakukan secara acak. Metode observasi yaitu mengetahui secara langsung tindak agronomi oleh petani yang membudidayakan melati.

Metode laboratorium dilakukan untuk menganalisis sifat kimia pada tanah sampel dan rendemen minyak atsiri bunga melati. Analisis sifat kimia tanah dilakukan di Laboratorium Pusat Penelitian Lingkungan Hidup Universitas Lambung Mangkurat, sedangkan analisis minyak atsiri bunga melati dilakukan di Laboratorium program studi Farmasi Universitas Lambung Mangkurat.

\section{Analisis Data}

\section{Analisis Deskriptif}

Analisis deskriptif dipergunakan untuk menjelaskan tentang gambaran umum wilayah penelitian meliputi tindak agronomi, sifat kimia tanah, produktivitas dan rendemen minyak atsiri bunga melati.

\section{Uji Asumsi Klasik}

Terdapat 3 uji asumsi klasik untuk pengujian hasil penelitian ini:

\section{Uji Normalitas}

Ujicoba normalitas bertujuan untuk melihat apakah data-data yang dihimpun berdistribusi normal atau tidak normal. Model regresi yang baik adalah memiliki distribusi data normal atau mendekati normal. Untuk mendeteksi normalitas data dilakukan uji statistik. Uji normalitas yang digunakan pada penelitian ini adalah Kolmogorov-Smirnov.

2.Uji Heteroskedastisitas

Uji ini dilakukan untuk melihat datadata penelitian yang didaptkan homogen serta sebalikya. Suatu model memenuhi asumsi homokesdastisitas jika memiliki varians error yang sama, yaitu nilai-nilai $Y$ bervariasi dalam satuan yang sama baik untuk nilai $\mathrm{X}$ yang tinggi maupun rendah. Metode pengujian pada penelitian ini adalah metode Glejser.

3.Uji Multikoliniearitas

Pengujian multikolinearitas dilakukan unutk mengetahui adanya suatu hubungan linier yang sempurna antar beberapa atau semua variable bebas. Adapun cara mendeteksi ada tidaknya multikolinieritas adalah apabila ada korelasi antara 2 variable bebas lebih tinggi dibandingkan salah satu atau kedua variable bebas tersebut dengan variable terikat. Sebagai indicator adanya multikoliniearitas adalah apabila korelasi antara dua variable bebas melebihi 10 maka multikolinearitas menjadi masalah dalam pengujian.

\section{Analisis Statistik Regresi Berganda}

Analisis data yang digunakan adalah metode regresi berganda. Analisis data ini bertujuan untuk mengetahui pengaruh faktor tindak agronomi dan sifat kimia tanah tehadap produktivitas bunga melati di Kabupaten Banjar dengan variabel dummy sebagai berikut: Pengaruh tindak agronomi dan sifat kimia tanah terhadap produktivitas bunga melati :

$$
\begin{aligned}
Y i= & b_{0}+b_{1} X_{1}+b_{2} X_{2}+b_{3} X_{3}+b_{4} X_{4}+b_{5} \\
& X_{5}+b_{6} X_{6}+b_{7} X_{7}+b_{8} X_{8}+b_{9} X_{9}+b_{10} \\
& X_{10}+b_{11} X_{11}+b_{12} X_{12}+b_{13} X_{13}+b_{14} \\
& X_{14}+b_{15} X_{15}+b_{16} X_{16}+b_{17} X_{17}+b_{18} \\
& X_{18}+b_{19} X_{19}
\end{aligned}
$$

Keterangan :

$\begin{array}{ll}\mathrm{Yi} & =\text { Produktivitas bunga melati } \\ \mathrm{b} 0 & =\text { Intersep } \\ \mathrm{b}_{1}, \mathrm{~b}_{2}, \mathrm{~b}_{3}, \ldots . \mathrm{b}_{19} & =\text { Koefisien regresi } \\ \mathrm{X}_{1} & =\text { Warna bahan setek } \\ & \text { (hijau,cokelat) } \\ \mathrm{X}_{2} & =\text { Umur bibit (tahun) } \\ \mathrm{X}_{3} & =\text { Jarak tanam }\left(\mathrm{m}^{2}\right)\end{array}$


$\mathrm{X}_{4} \quad=$ Pengolahan tanah (variable dummy, melakukan pengolahan tanah $=1$, tidak melakukan pengolahan tanah $=0$ )

$\mathrm{X}_{5} \quad=$ Sumber air

$\mathrm{X}_{6} \quad=$ Pupuk N (kg/tahun)

$\mathrm{X}_{7} \quad=$ Pupuk P $(\mathrm{kg} /$ tahun $)$

$\mathrm{X}_{8} \quad=$ Pupuk K $(\mathrm{kg} /$ tahun $)$

$\mathrm{X}_{9} \quad=$ Frekuensi Pemupukan (kali / tahun)

$\mathrm{X}_{10} \quad=$ Pupuk Organik (variable dummy, memberikan pupuk organik $=1$, tidak memberikan pupuk organik

$=0$ )

$\begin{array}{llr}\mathrm{X}_{11} & \text { Penyiangan } & \text { (variable } \\ & \text { dummy, } & \text { melakukan } \\ & \text { penyiangan = } 1, \text { tidak } \\ & \text { melakukan penyiangan }=0)\end{array}$

$\mathrm{X}_{12} \quad=$ Penyulaman $\quad$ (variable dummy, melakukan penyulaman $=1$, tidak melakukan penyulaman $=0$ )

$\mathrm{X}_{13} \quad=$ Peubah pengendalian opt (variable dummy, melakukan pengendalian opt $=1$, tidak melakukan pengendalian $\mathrm{opt}=0$ )

$\mathrm{X}_{14} \quad=$ Peubah pemangkasan (kali/tahun)

$\mathrm{X}_{15} \quad=\mathrm{C}$ - organik

$\mathrm{X}_{16} \quad=\mathrm{N}$ (Nitrogen)

$\mathrm{X}_{17} \quad=\mathrm{P}$ (Fosfor)

$\mathrm{X}_{18} \quad=\mathrm{K}$ (Kalium)

$\mathrm{X}_{19} \quad=\mathrm{pH}$

Agar peneliti tahu apakah faktor peubah variabel bebas secara keseluruhan berpengaruh terhadap peubah variabel tidak bebas, maka digunakan ragam regresi dan uji $\mathrm{F}$ melalui analisa varian pada tingkat kepercayaan $95 \%$.

Apabila nilai $\mathrm{F}$ hit $<\mathrm{F}$ tab artinya diambil kesimpulan yaitu peubah-peubah bebas secara simultan (bersama) tak ber pengaruh nyata terhadap variabel-variabel bebas, sebaliknya apabila nilai $\mathrm{F}$ hit $>\mathrm{F}$ tab dapat disimpulkan jika peubah-peubah bebas secara bersama-sama berpengaruh nyata kepada variabel-variabel tak bebas. Apabila peubah-peubah bebas secara stimultan berpengaruh nyata terhadap variabelvariabel tak bebas, maka perlu mengetahui peubah-peubah bebas mana yang memiliki pengaruh atau tidak terhadap peubah-peubah tak-bebas dilanjutkan Uji Regresi secara Parsial.

\section{Regresi Linear Sederhana}

Regresi liniear sederhana dilakukan untuk mengetahui aoakah peubah bebas $\mathrm{X}$ (tindak agronomi dan sifat kimia tanah) memiliki hubungan terhadap peubah respon (produktivitas). Model regresi yang digunakan adalah:

$$
\mathrm{Y}_{\mathrm{i}}=\beta \mathrm{o}+\beta_{1} \mathrm{Xi}+\varepsilon_{\mathrm{i}}
$$

Keterangan :

$\begin{array}{ll}\mathrm{Yi} & =\text { Peubah tak bebas (peubah } \\ & \text { respon) } \\ \beta_{\mathrm{O}} & =\text { Koefisien intersep } \\ \beta_{1} & =\text { Koefisien regresi }\end{array}$

Analisis Jalur (Path Cofficient Analysis)

Analisis jalur yaitu teknik analisis sebab akibat yang terjadi pada regresi berganda, apabila variabel bebasnya mempengaruhi terhadap variabel terikat tidak hanya secara langsung namun juga secara tidak langsung. Analisis jalur merupakan analsis terapan dari analisis multiregresi untuk membantu memudahkan pengujian hipotesis dari hubungan-hubungan antar variabel. Analisis jalur digunakan untuk menganalisis pola hubungan antar variabel dengan tujuan mengatahui pengaruh langsung serta tidak langsung. Pengaruh langsung peubah sebab $\mathrm{X}_{\mathrm{i}}$ terhadap peubah akibat $\mathrm{Y}$ diukur dengan koefisien lintas:

$$
\mathrm{P}_{\mathrm{yi}}=\mathrm{b}_{\mathrm{yi}} \underline{\underline{\mathrm{Sx}}}
$$

Dimana Sx dan sy masing-masing adalah simpangan baku, simpangan baku peubah $\mathrm{X}$ dan $\mathrm{Y}$, sedangkan $\mathrm{b}_{\mathrm{yi}}$ adalah koefisien regresi dengan persamaan berikut: $(\mathrm{Y}-\mathrm{Y})=\mathrm{b}_{\mathrm{y}} 1\left(\mathrm{X}_{1}-\mathrm{X}_{1}\right)+\mathrm{b}_{\mathrm{y}} 2\left(\mathrm{X}_{2}-\mathrm{X}_{2}\right)+\mathrm{b}_{\mathrm{y}} 3$ $\left(\mathrm{X}_{3}-\mathrm{X}_{3}\right)+\ldots+\mathrm{b}_{\mathrm{y}} \mathrm{i}\left(\mathrm{X}_{\mathrm{i}}-\mathrm{X}_{\mathrm{i}}\right)$ 
Pengukuran koefisien lintas selain menggunakan cara tersebut diatas yaitu melalui pendekatan regresi berdasarkan matriks korelasi. Data penelitian akan dianalisis dengan menggunakan bantuan program Minitab 16 statistical software dan SPSS Statistic Version 25.

\section{HASIL DAN PEMBAHASAN}

\section{Uji Asumsi Normalitas}

Hasil pengujian normalitas Kolmogorov-Smirnov dilakukan untuk memastikan apakah suatu peubah data mendekati distribusi normal. Hasil menunjukkan bahwa peubah data bebas (independent variable) dan peubah tergantung (dependent variable) menyebar secaranormal karena nilai prob sebesar 0,125 yang lebih besar dari taraf nyata $\alpha=5$ persen $(\mathrm{P}>0.05)$, maka disimpulkan error term menyebar normal (Gambar 1).

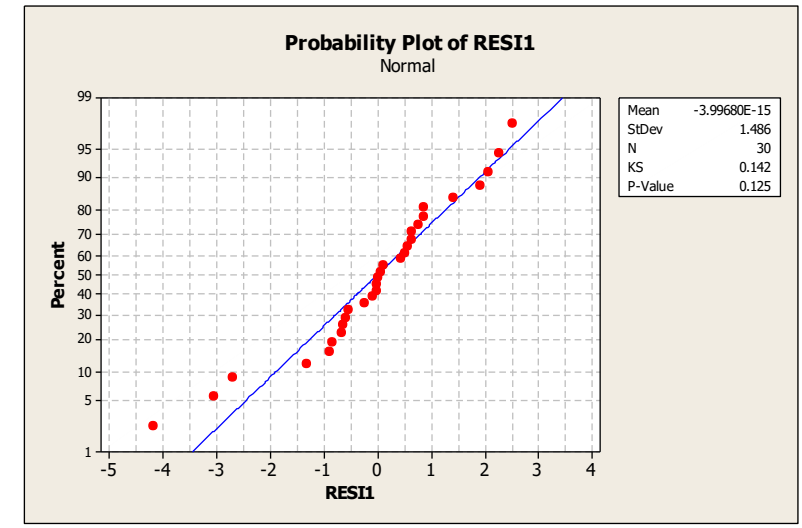

Gambar 1. Uji normalitas kolmogorovsmirnov pada data tindak agronomi, sifat kimia tanah terhadap produktivitas tanaman melati di kabupaten Banjar

\section{Uji Heteroskedastisitas}

Uji heteroskedastisitas merupakan salah satu pengujian untuk mendeteksi heteroskedastik adalah dengan Uji Statistik metode Glejser. Pengujian ini meregresikan residual kuadrat sebagai variabel dependen pada regresor asli.

Tabel 1. Hasil uji heteroskedastik metode Glejser

\begin{tabular}{|c|c|c|c|c|c|c|}
\hline \multirow[t]{2}{*}{ No } & Model & & $\begin{array}{l}\text { ldardized } \\
\text { ficients }\end{array}$ & $\begin{array}{l}\text { Coeff }^{\mathbf{a}} \\
\text { Standardized } \\
\text { Coefficients }\end{array}$ & $\mathrm{T}$ & Sig. \\
\hline & & $\mathrm{B}$ & Std. Error & Beta & & \\
\hline & (Constant) & -1.312 & 6.699 & & -.196 & .848 \\
\hline 1 & $\mathrm{X} 1$ & .911 & .756 & .222 & 1.205 & .252 \\
\hline 2 & $\mathrm{X} 2$ & 1.217 & 3.789 & .061 & .321 & .754 \\
\hline 3 & X3 & -.013 & .008 & -.293 & -1.618 & .132 \\
\hline 4 & $\mathrm{X} 4$ & -.015 & .092 & -.051 & -.168 & .870 \\
\hline 5 & X5 & .193 & .575 & .074 & .337 & .742 \\
\hline 6 & X6 & .874 & 2.574 & .158 & .339 & .740 \\
\hline 7 & $\mathrm{X7}$ & 1.256 & .561 & .359 & 2.240 & .045 \\
\hline 8 & $\mathrm{X} 8$ & .542 & .925 & .121 & .586 & .569 \\
\hline 9 & X9 & -.002 & .009 & -.072 & -.230 & .822 \\
\hline 10 & $\mathrm{X} 10$ & .611 & .495 & .222 & 1.234 & .241 \\
\hline 11 & $\mathrm{X} 11$ & .005 & .002 & .782 & 2.223 & .046 \\
\hline 12 & $\mathrm{X} 12$ & -.004 & .004 & -.212 & -.842 & .416 \\
\hline 13 & $\mathrm{X} 13$ & .000 & .002 & .058 & .208 & .838 \\
\hline 14 & X14 & -.115 & .135 & -.250 & -.846 & .414 \\
\hline 15 & $\mathrm{X} 15$ & .671 & .943 & .190 & .712 & .490 \\
\hline
\end{tabular}




\begin{tabular}{lllllll}
\hline 16 & $\mathrm{X} 16$ & .129 & 3.293 & .014 & .039 & .969 \\
17 & $\mathrm{X} 18$ & .068 & .478 & .046 & .143 & .889 \\
\hline
\end{tabular}

\section{Uji multikolinearitas}

Uji non- multikolieniritas merupakan suatu keadaan dimana terjadi linear yang sempurna di antara variabel penjelas yang dimasukkan ke dalam model. Prasyarat yang harus terpenuhi dalam model regresi adalah tidak adanya terjadi multikolieniritas.

Pada hasil penelitian ini dalam mendeteksi gejala multikolinearitas adalah dengan mengamati nilai varians inflation factor (VIF) dapat dilihat dikolom Tabel 2 yang menjelaskan bahwa nilai Variance Inflation Factor (VIF) pada semua peubah peubah bebas (X) terhadap peubah tergantungnya (Y) menunjukkan nilai VIF $<10$. Hal ini menunjukkan tidak terjadi multicolinearity antar peubah-peubah bebas $\mathrm{X}$ sebagai regresor.

\section{Analisis Hubungan Tindak Agronomi Dan Sifat Kimia Tanah terhadap Produktivitas Tanaman Melati}

Tindak agronomi yang terdiri atas bahan stek (X1), umur bahan (X2), pengolahan tanah (X3), jarak tanam (X4), sumber air (X5), pupuk $\mathrm{N}$ (X6), pupuk $\mathrm{P}$ (X7), pupuk K (X8), frekuensi pemupukan (X9), pupuk organik (X10), penyiangan (X11), frekuensi pemangkasan (X12) dan sifat kimia tanah C-organik (X13), N (X14), $\mathrm{P}$ (X15), K (X16), dan $\mathrm{pH}$ (X17) secara simultan memberikan pengaruh yang nyata terhadap produktivitas tanaman melati dengan persamaan regresi sebagai berikut:

$\overline{\mathrm{Y}}=-3.19+0.0045 \mathrm{x}_{1}+1.007 \mathrm{x}_{2}+0.693 \mathrm{x}_{3}+0.00129 \mathrm{x}_{4}+1.4726 \mathrm{x}_{5}+0.013024 \mathrm{x}_{6}+-$ $0.001291 \mathrm{x}_{7}+0.007505 \mathrm{x}_{8}+0.0922 \mathrm{x}_{9}+-0.408 \mathrm{x}_{10}+-4.067 \mathrm{x}_{11}+2.0081 \mathrm{x}_{12}+0.674 \mathrm{x}_{13}+$ $6.549 \mathrm{x}_{14}+0.00564 \mathrm{x}_{15}+0.0016 \mathrm{x}_{16}+-1.011 \mathrm{x}_{17}$ dan $\mathrm{R}^{2}=92.43 \%$

Tabel 2. Hasil uji multikolinearitas

\begin{tabular}{lc}
\hline \multicolumn{1}{c}{ Predictor } & Variance inflation factor (VIF) \\
\hline Bahan Stek & 4.259 \\
Umur Bahan & 1.512 \\
Pengolahan Tanah & 2.230 \\
Jarak Tanam & 2.653 \\
Sumber Air & 2.041 \\
Nitrogen & 5.411 \\
Fosfat & 3.165 \\
Kalium & 2.835 \\
Frekuensi Pemupukan & 4.158 \\
Pupuk Organik & 2.350 \\
Penyiangan & 3.715 \\
Frek. Pemangkasan & 3.018 \\
C & 1.777 \\
N & 2.059 \\
P & 1.690 \\
K & 2.456 \\
pH & 2.689 \\
\hline
\end{tabular}


Tabel 3. Analisis regresi parsial tindakan agronomi dan sifat kimia tanah terhadap produktivitas tanaman melati

\begin{tabular}{lclrl}
\hline Predictor & Coef & SE Coef & T & \multicolumn{1}{c}{$\mathbf{P}$} \\
\hline Constant & -3.19 & 10.46 & -0.31 & 0.766 \\
bahan stek & 0.045 & 2.902 & 0.02 & 0.988 \\
umur bahan tanam & 1.007 & 1.089 & 0.92 & 0.374 \\
pengolahan tanah & 0.693 & 1.690 & 0.41 & 0.689 \\
jarak tanam & 0.0129 & 0.01224 & 1.05 & 0.312 \\
sumber air & 1.4726 & 0.9967 & 1.48 & 0.165 \\
Nitrogen & 0.013014 & 0.003527 & 3.69 & $0.003 * *$ \\
Fosfat & -0.001291 & 0.007998 & -0.16 & 0.874 \\
Kalium & 0.007505 & 0.002421 & 3.10 & $0.014 *$ \\
Frek. pemupukan & 0.0922 & 0.2371 & 0.39 & 0.704 \\
pupuk organik & -0.408 & 1.296 & -0.31 & 0.759 \\
penyiangan & -4.067 & 2.710 & -1.50 & 0.159 \\
frek. pemangkasan & 2.0081 & 0.6581 & 3.05 & $0.010 *$ \\
C & 0.674 & 1.386 & 0.49 & 0.636 \\
N & 6.549 & 7.231 & 0.91 & 0.383 \\
P2O5 & 0.00564 & 0.01482 & 0.38 & 0.710 \\
K2O & 0.0016 & 0.1192 & 0.01 & 0.990 \\
pH & -1.011 & 1.080 & -0.94 & 0.367 \\
\hline
\end{tabular}

Keterangan : $\quad *=$ Berpengaruh nyata $(\mathrm{P}<0.05>0.01)$;

$* *=$ Berpengaruh sangat nyata $(\mathrm{P}<0.01)$

Berdasarkan nilai koefisien determinasi $\left(\mathrm{R}^{2}\right)$ persamaan tersebut menjelaskan sumbangan $\mathrm{X}$ (peubah sebab) terhadap keragaman $\mathrm{Y}$ sebesar $92,43 \%$, sedangkan yang tidak terjelaskan dari persamaan tersebut sebesar 7,57\%. Pada penelitian ini pemberian pupuk Nitrogen $(\mathrm{N})$ berpengaruh sangat nyata terhadap produktivitas tanaman melati di Kabupaten Banjar, sedangkan pupuk Kalium (K) dan frekuensi pemangkasan masing-masing berpengaruh nyata yang dapat dilihat pada Tabel 3.

\section{Hubungan pemberian pupuk $\mathrm{N}$ terhadap produktivitas tanaman melati}

Hasil analisis linier sederhana menunjukkan bahwa pemberian pupuk $\mathrm{N}$ memperlihatkan hubungan linier sangat nyata akan produktivitas tanaman melati dan persamaan regresinya adalah $5.173+$ $0.01526 \mathrm{~N}$ dan koefisien determinasi $\left(\mathrm{R}^{2}\right)=$ $63,9 \%$ yang dapat dilihat pada Gambar 2 .

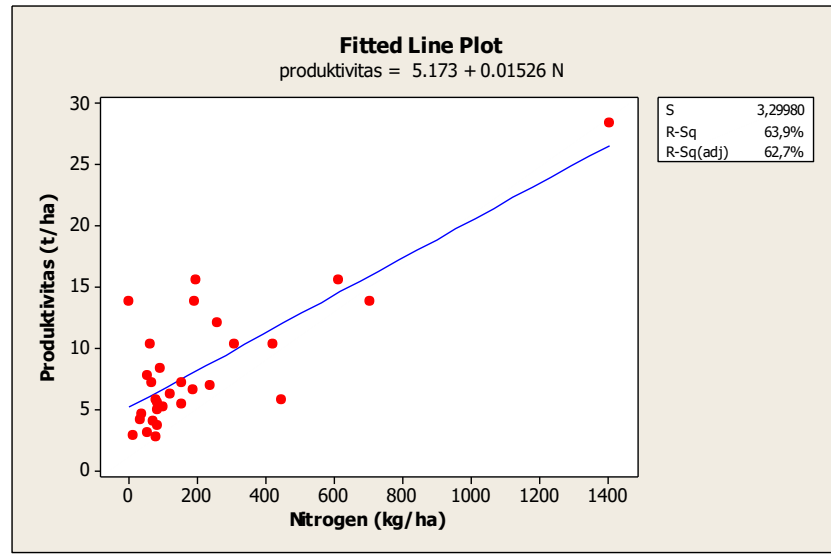

Gambar 2. Hubungan pemberian nitrogen terhadap produktivitas 
Berdasarkan koefisien determinasi tersebut menunjukkan $63,9 \%$ model regresi tersebut menjelaskan sumbangan peubah bebas nitrogen terhadap produktivitas tanaman melati. Sedangkan $36,1 \%$ tidak dijelaskan oleh model.Pada Gambar 2 dapat dilihat semakin ditingkatkan pupuk $\mathrm{N}$, maka produktivitas akan meningkat pula. Setiap peningkatan satu satuan pupuk nitrogen $(\mathrm{kg})$ maka meningkatkan produktivitas sebesar $15,26 \mathrm{~kg} \mathrm{ha}^{-1}$. Hasil analisis regresi parsial menerangkan bahwa pemberian pupuk $\mathrm{N}$ mempunyai pengaruh sangat nyata terhadap produktivitas tanaman melati. Pemberian pupuk $\mathrm{N}$ ini berasal dari pupuk urea, pupuk majemuk $(\mathrm{N}, \mathrm{P}, \mathrm{K})$ dari merek dagang phonska dan mutiara. Hal ini menunjukkan bahwa peranan pupuk $\mathrm{N}$ berpengaruh terhadap pertumbuhan tanaman. Menurut Pangaribuan (2012) unsur hara N punyai peran untuk merangsang pertumbuhan vegetatif tanaman, sehingga mampu memacu pertumbuhan hingga produktivitas tanaman melati. Rata-rata pemberian pupuk $\mathrm{N}$ yang diberikan petani dosisnya $212,46 \mathrm{~kg}$ $\mathrm{N}$ ha $^{-1}$ tahun $^{-1}$.

\section{Hubungan frekuensi pemangkasan terhadap produktivitas tanaman melati}

Berdasarkan hasil analisis regeresi frekuensi pemangkasan(tahun) menunjukkan hubungan linier sangat nyata terhadap produktivitas tanaman melati dan persamaan regresinya adalah $-0.194+3.587$ pemangkasan dan koefisien determinasi $\left(\mathrm{R}^{2}\right)=56,6 \%$ yang dapat dilihat ada Gambar 3 .

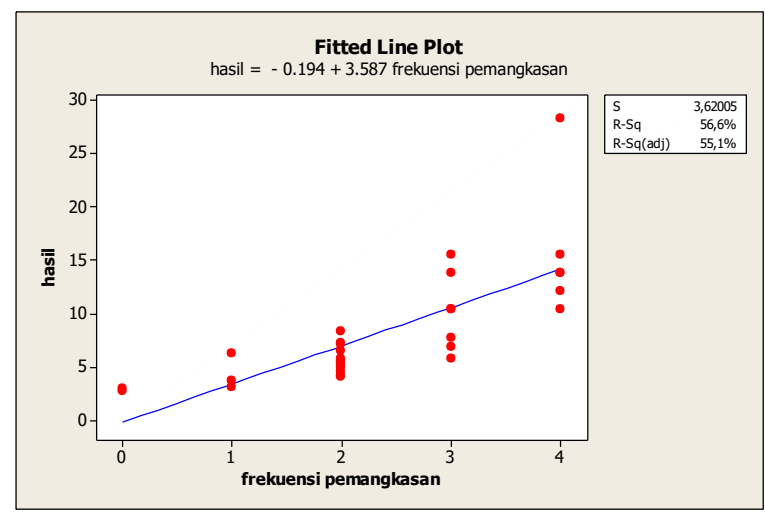

Gambar 3.Hubungan frekuensi pemangkasan terhadap produktivitas

Berdasarkan koefisien determinasi tersebut menunjukkan 56,6\% model regresi tersebut menjelaskan sumbangan peubah bebas nitrogen terhadap produktivitas tanaman melati. Sedangkan, $43,4 \%$ tidak dijelaskan oleh model. Hasil penelitian menunjukkan frekuensi pemangkasan berpengaruh nyata terhadap produktivitas tanaman melati. Frekuensi pemangkasan diduga telah merangsang pertumbuhan munculnya tunas-tunas (Destifa, 2016) yang berarti semakin banyak muncul tunas yang produktif pada ujung ranting, maka dimungkinkan akan lebih banyak kemunculan bunga. Semakin banyak jumlahan daun, maka kemampuan membentuk fotosintat akan semakin besar, sehingga pembentukan organ-organ vegetatif tanaman lebih baik (Taiz dan Zeiger, 2002). Frekuensi pemangkasan 
tanaman melati yang dilakukan petani melati di Kabupaten Banjar berkisar antara 0 4kali dengan rata-rata 2,4 kali (dibulatkan 2 kali).

\section{Rendemen Minyak Atsiri Melati}

Minyak atsiri dipisahkan dari fase air, kemudian didiamkan hingga berada pada suhu ruangan. A adalah minyak atsiri bunga melati berwarna kuningpucat, bau khas melati, bentuk cair, sedangkan B adalah fase air hasil destilasi berwarna putih keruh, bau khas melati, bentuk cair yang dapat dilihat pada Gambar 4. Rendemen minyak atsiri melati yang didapat yaitu kisaran 0,13 - 0,14 $\%$ dengan rata-rata $0,133 \%$.

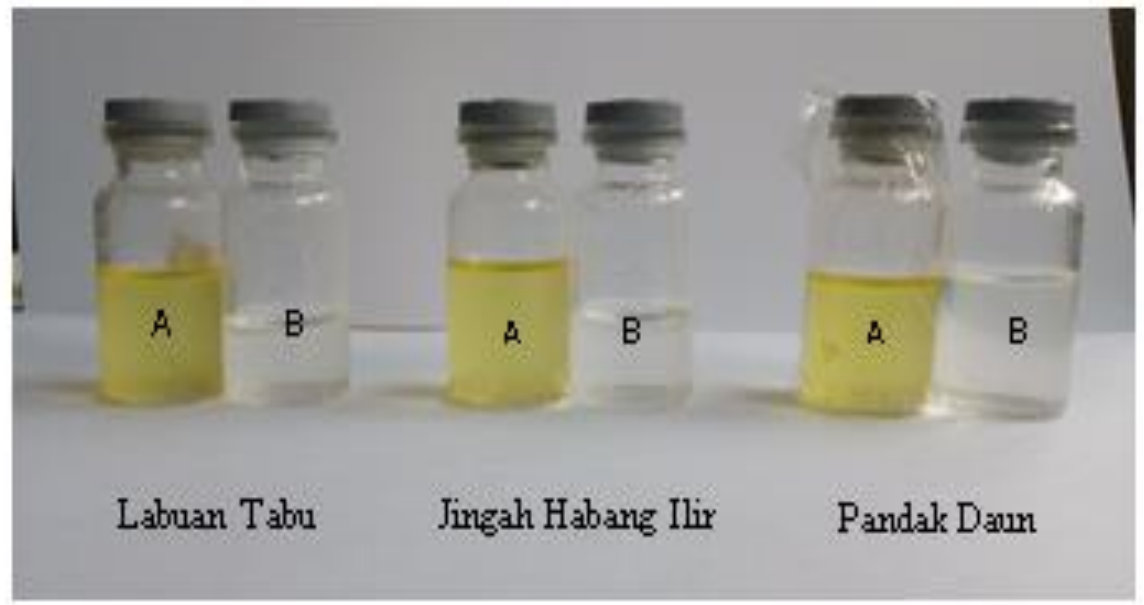

Keterangan: $\mathrm{A}=$ Minyak atsiri melati $\mathrm{B}=$ fase air hasil destilasi melati

Gambar 4. Rendemen minyak atsiri melati

\section{Analisis Jalur (Path Cofficient Analysis)}

Berdasarkan hasil analisis regresi berganda, untuk menggambarkan mekanisme hubungan antara tindak agronomi dan sifat kimia tanah terhadap produktivitas tanaman melati dilakukan analisis jalur yang dapat di lihat pada Tabel 4.

Tabel 4. Pengaruh langsung tindak agronomi dan sifat kimia tanah terhadap produktivitas tanaman melati

\begin{tabular}{lcc}
\hline Peubah & $\begin{array}{c}\text { Pengaruh langsung } \\
\left(\mathbf{P}_{\mathbf{i j}}\right)\end{array}$ & Sumbangan pengaruh langsung (\%) \\
\hline $\mathrm{BS}=\mathrm{X} 1$ & 0.003 & 0.0009 \\
$\mathrm{UB}=\mathrm{X} 2$ & 0.090 & 0.0081 \\
$\mathrm{PT}=\mathrm{X} 3$ & 0.049 & 0.240 \\
$\mathrm{JT}=\mathrm{X} 4$ & 0.0137 & 0.0188 \\
$\mathrm{SA}=\mathrm{X} 5$ & 0.168 & 2.82 \\
$\mathrm{PN}=\mathrm{X} 6$ & 0.682 & 46.51 \\
$\mathrm{PP}=\mathrm{X} 7$ & -0.023 & 0.053 \\
$\mathrm{PK}=\mathrm{X} 8$ & 0.414 & 17.14 \\
$\mathrm{FP}=\mathrm{X} 9$ & 0.063 & 0.397 \\
$\mathrm{PO}=\mathrm{X} 10$ & -0.038 & 0.144 \\
\hline
\end{tabular}




$\begin{array}{lcc}\mathrm{PNy}=\mathrm{X} 11 & -0.230 & 5.29 \\ \mathrm{FPks}=\mathrm{X} 12 & 0.421 & 17.72 \\ \mathrm{C}=\mathrm{X} 13 & 0.051 & 0.260 \\ \mathrm{~N}=\mathrm{X} 14 & 0.103 & 1.061 \\ \mathrm{P}=\mathrm{X} 15 & 0.039 & 0.152 \\ \mathrm{~K}=\mathrm{X} 16 & 0.002 & 0.0004 \\ \mathrm{pH}=\mathrm{X} 17 & -0.122 & 1.488\end{array}$

Keterangan : $B S=$ Bahan stek, $U B=$ Umur Bahan, $P T=$ Pengolahan tanah, $J T=$ Jarak Tanam, SA =Sumber air, $P N$ $=$ Pupuk Nitrogen, $P P=$ Pupuk Fosfat, $P K=$ Pupuk Kalium; $P O=$ Pupuk Organik, PNy = Penyiangan, FPks = Frekuensi pemangkasan, $C$-organik; $N$-tanah, $P=P$ tanah, $K=K$-tanah, dan $p H$

Pada Tabel 4 dapat dilihat pengaruh langsung tindak agronomi, pemberian pupuk nitrogen lebih dominan pengaruhnya terhadap produktivitas tanaman melati yang memberikan sumbangan pengaruh sebesar $46,51 \%$. Kemudian diikuti frekuensi pemangkasan dengan sumbangan pengaruh sebesar $17,72 \%$, dan pemberian pupuk kalium sebesar 17,14\%. Sedangkan tindak agronomi seperti bahan stek, umur bibit, pengolahan tanah, jarak tanam, sumber air, pemberian pupuk fosfat, frekuensi pemberian pupuk, pupuk organik, dan penyiangan masing-masing sumbangan pengaruhnya sangat kecil. Demikian pula dengan sifat kimia tanah seperti C-organik, Unsur $\mathrm{P}, \mathrm{N}, \mathrm{K}$, dan $\mathrm{pH}$ masing-masing pengaruhnya sangat kecil terhadap produktivitas tanaman melati di Kabupaten Banjar. Untuk mengetahui pengaruh tidak langsung tindak agronomi terhadap produktivitas dapat dilihat pada Gambar 5.

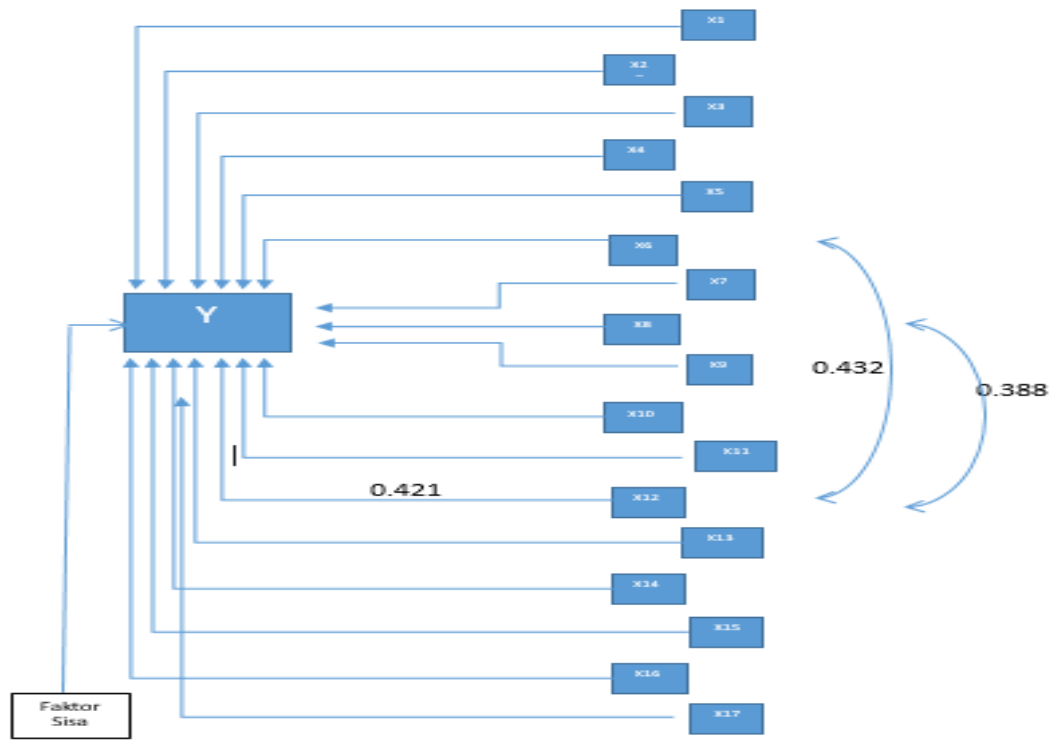

Gambar 5. Lintasan pengaruh tak langsung tindak agronomi terhadap prosuktivitas tanaman melati

Pengaruh tak langsung pemberian pupuk nitrogen terhadap produktivitas tanaman melati melalui peubah frekuensi pemangkasan adalah $(0.432 \times 0.421=$ 0.1819). Hal ini menunjukkan peranan pemberian pupuk nitrogen yang disalurkan 
melalui frekuensi pemangkasan(tahun) walaupun pengaruhnya kecil akan meningkatkan pengaruh frekuensi pemangkasan terhadap produktivitas yaitu sebesar 18,19 \% meningkat dibandingkan dengan pengaruh langsung frekuensi pemangkasan. Pengaruh tak-langsung pemberian pupuk nitrogen yang disalurkan melaui peubah tindak agronomi lainya atau sifat kimia tanah tidak menunjukkan perubahan pengaruh dibandingkan dengan pengaruh langsungnya. Demikian pula dengan pengaruh tak langsung pemberian pupuk kalium (K) terhadap produktitas tanaman melati yang disalurkan melalui frekuensi pemangkasan, walaupun pengaruhnya kecil $(0.388 \times 0.421=0.1633)$, akan memberikan sumbangan pengaruh seebesar $16,33 \%$. Jjika pengaruh taklangsungnya disalurkan melalui peubah lainnya, maka pengaruhnya menjadi sangat kecil dibandingkan dengan pengaruh langsungnya.

\section{KESIMPULAN}

1. Tindak agronomi dan sifat kimia tanah secara simultan berpengaruh nyata terhadap produktivitas tanaman melati. Pemberian pupuk $\mathrm{N}, \mathrm{K}$ dan frekuensi pemangkasan(tahun) masing-masing berpengaruh nyata terhadap produktivitas tanaman melati.

2. Tindak agronomi yang dominan adalah pemberian $\mathrm{N}, \quad$ frekuensi pemangkasan(tahun), dan $\mathrm{K}$ dengan besaran sumbangan terhadap produktivitas tanaman melati masingmasing sebesar $46,51 \%, 17,72 \%$, dan $17,14 \%$.

3. Pengaruh tak langsung pemberian pupuk $\mathrm{N}$ yang disalurkan melalui frekuensi pemangkasan(tahun) memberikan sumbangan sebesar $18,19 \%$ lebih tinggi dari pengaruh langsung frekuensi pemangkasan. Pengaruh tak langsung pemberian pupuk $\mathrm{K}$ melalui frekuensi pemangkasan memberikan sumbangan sebesar $16,33 \%$ terhadap produktivitas tanaman melati.

4. Pemberian pupuk $\mathrm{N}$ dan frekuensi pemangkasan (tahun) menunjukkan hubungan sangat nyata linier positif terhadap produktivitas dengan persamaan regresi masing-masing 5.173 $+0.01526 \mathrm{~N}$ dan $-0.194+3.587$ pemangkasan. Rendemen minyak atsiri melati di Kabupaten Banjar berkisar antara $0,13 \%-0,136 \%$ dengan rata-rata $0,133 \%$.

\section{DAFTAR PUSTAKA}

Bastiah, Masyhudah, R dan Yusuf, A. 2019. Analisis biaya pendapatan dan keuntungan perangkai bunga melati (Jasminum sambac) diKecamatan Martapura Kabupaten Banjar. Frontier Agribisnis 3 (4), Desember $2019-83$.

Badan Pusat Statistik. 2018. Statistik Tanaman Hias Indonesia.Hal 40-41.

Destifa R.E. 2016. Pengaruh Pemangkasan Dan Pemberian Pupuk Majemuk Terhadap Pertumbuhan Vegetatif Tanaman Jambu Biji Merah (Psidium guajava L.) Kultivar Citayam. Universitas Lampung. Indonesia.

Dinas Tanaman Pangan dan Hortikultura Kabupaten Banjar. 202). Daftar Isian Profil Wilayah Sentra Produksi Melati Di Kabupaten Banjar Provinsi Kalimantan Selatan.

Direktorat Jendral Hortikultura Kementrian Pertanian. 202). Potensi Pengembangan Melati Kabupaten Banjar.

Nababan, A. 2003. Pengelolaan Sumberdaya Alam Berbasis Masyarakat Adat. Pelatihan Pengelolaan Lingkungan Hidup Daerah, Pusat Penelitian Lingkungan Hidup IPB, Bogor. 
Pangaribuan, Darwin H. 201). Pegaruh Pupuk Organik Cair Terhadap Pertumbuhan dan Produksi Sayuran Kangkung, Bayam, dan Caisim. Prosiding Seminar Nasional PERHORTI 2012.

Provinsi Kalimantan Selatan dalam Angka. 202). Badan Pusat Statistik Kalimantan Selatan. P.395.

Setyawati, AS. 2015. Budidaya tanaman melati (Jasminum spp.). Balai
Penelitian Tanaman Hias. Iptek hortikultura no. 11 Tabloid Sinartani. 2019. Begini Cara Barantan Agar Melati Indonesia Masuk Ekspor. Diakses $\quad 31 \quad$ oktober 2020 http://Tabloidsinartani.com.

Taiz, L., E. Zeiger. 2002. Plant Physiology. California. The Benjamin Cummings Publishing Co. Inc., Redwood City, CA. Wright, C.J. 1989 